OPEN ACCESS

Edited by:

Jérôme Abadie,

Agroalimentaire et de l'alimentation de

Nantes-Atlantique (Oniris), France

Reviewed by:

Danielle Darracq Nelson,

Washington State University,

United States

Javier Asin,

University of California, San

Bernardino, United States

*Correspondence:

Steffen Maak

maak@fbn-dummerstorf.de

Specialty section:

This article was submitted to

Veterinary Experimental and

Diagnostic Pathology,

a section of the journal

Frontiers in Veterinary Science

Received: 24 September 2020

Accepted: 25 January 2021

Published: 26 February 2021

Citation:

Schumacher T, Röntgen M and Maak S (2021) Congenital Splay Leg

Syndrome in Piglets-Current Knowledge and a New Approach to Etiology. Front. Vet. Sci. 8:609883.

doi: 10.3389/fvets.2021.609883

\section{Congenital Splay Leg Syndrome in Piglets-Current Knowledge and a New Approach to Etiology}

\author{
Toni Schumacher, Monika Röntgen and Steffen Maak* \\ Institute of Muscle Biology and Growth, Leibniz Institute for Farm Animal Biology, Dummerstorf, Germany
}

The porcine congenital splay leg syndrome (PCS), even though being of transient nature, is still one of the most important causes for piglet losses due to its high incidence and mortality. Although, described decades ago, the pathogenetic mechanism is still elusive. Numerous, mostly descriptive studies characterized the syndrome at clinical, histological and cellular levels but resulted in a highly diverse picture of the syndrome. Broad variability in phenotypical expression and, in case of proper care, the rapid recovery of affected animals complicated a systematical analysis of the underlying pathogenesis. Although, several environmental factors were discussed as potential causes of PCS, most of the evidence points to a hereditary basis of PCS. Nevertheless, only few of the suggested candidate genes from transcriptome and mapping analyses, like F-box protein 32 (FBXO32), could be confirmed so far. Only recently, a genome wide association study revealed genomic regions on five porcine chromosomes and named a number of potential candidate genes, among them homer scaffold protein 1 (HOMER1). This new candidate-a cellular scaffold protein - plays a role in a plethora of cellular signaling cascades, and is not only involved in skeletal muscle differentiation but also critical for muscular function. In this review, we critically elucidate the current state of knowledge in the field and evaluate current achievements in the identification of the pathogenetic mechanism for the syndrome.

Keywords: congenital splay leg syndrome, piglet, myofibrillar hypoplasia, HOMER1, FBXO32

\section{INTRODUCTION}

The porcine congenital splay leg syndrome (PCS) or spraddle leg syndrome is generally considered as one of the most frequent developmental defects in piglets (1). This condition is characterized by a lateral abduction of the hind limbs in newly born animals while the forelegs are affected only in severe cases. This leads to an impaired ability of the piglets to walk or even stand and increases the risk of being crushed by the sow or to die of starvation. Losses among affected piglets are high and discussion is still ongoing whether muscle function remains impaired throughout life of surviving piglets $(2,3)$. Consequently, PCS is highly relevant for the pig industry due to economic reasons as well as for animal welfare issues. The splay leg syndrome is generally transient and animals will recover within a few days if treated properly (4). Tying the affected hind legs immediately after birth increases mobility, ensures proper nutrition and is mostly sufficient to decrease mortality rates significantly (5). 
Despite more than 50 years of research in different countries with large scale and intensive pig production like the USA (3), Canada (6), Germany (7), Australia (8), Czech Republic $(9,10)$, neither the etiology nor the pathogenic mechanisms of the splay leg syndrome are fully understood. Histological, histochemical and biochemical analyses were mainly performed from the 1960's to the 1990's describing more or less typical features of delayed muscle maturation $(11,12)$. Early on, herd level analyses suggested a hereditary predisposition due to breed specific incidence rates and effects of mated boars (13). With increasing availability of methods for genome-wide, molecular analyses, studies aimed at the elucidation of genetic causes of PCS at both, transcriptome and genome level since the early 2000's (14-16). However, the transient nature as well as the phenotypic variability of PCS, and the snap-shot-like picture provided by transcriptome analyses led to limited insight into the pathological mechanisms although, a number of functional candidates were provided for further analyses. Only recently, a genome wide association study (GWAS) revealed different genomic regions on five porcine chromosomes of which some contain promising candidate genes for PCS (17).

This review provides a comprehensive update on the current knowledge about PCS and highlights new approaches for future research.

\section{INCIDENCE AND MORTALITY}

Reports on the incidence of PCS differ considerably depending on breed, scale of farms, and country. Early data from largescale production units in East Germany indicated a proportion of $22-33 \%$ affected piglets among all piglets born alive. Almost $5 \%$ had to be culled $(18,19)$. In contrast, incidences of 5$7.5 \%$ were reported under similar production regimens by other authors while between 21 and $36 \%$ of all litters were affected $(20,21)$. In a more recent investigation $0.2 \%$ splay leg piglets were counted among all piglets born alive whereas $1.2 \%$ of all piglets were affected in German Landrace and their crosses with Pietrain (22). Between 0.12 and $1.42 \%$ of all born piglets were affected by the syndrome in Large White and Landrace in Great Britain in 1972. Similar results were stated for other European countries, Canada and Australia (23). Nowadays, it is assumed that the general incidence ranges from 1 to $8 \%$ worldwide (24), although newer, more comprehensive records are not available. The results also clearly indicate that large pig facilities are more often affected. While housing and breeding conditions certainly play a significant role in splay leg incidence, there is also clear evidence for hereditary factors causing PCS.

Several studies found differing incidences clearly related to genetic background and sex. Already in 1971 it was shown that male piglets are affected disproportionately high and that the gender ratio is roughly 2:1 favoring incidence in male vs. female (13) which was not consistently confirmed by others $(21,25,26)$. Effects of litter size were also discussed but were not found significant in a larger study over several years (26). Beside the gender effect, there must be other hereditary factors since later it was also found that certain breeds tend to have higher incidences. For example, Landrace crossbred pigs had significantly higher proportions of splay leg piglets in comparison to progeny of Yorkshire and Duroc (26) and thus confirmed an earlier study (20). Landrace for example showed a nearly 10 -fold higher incidence of PCS compared to Large White and hybrids were characterized by intermediate incidences (23). It is therefore reasonable to view congenital splay leg as a hereditary disease. With $45 \%$ of all recorded inherited defects, it even represents the largest group of hereditary birth defects in pigs $(23,27)$.

Due to the high incidence, splay leg syndrome was the second most common cause of piglet mortality (22\%) with a general lethality of up to $50 \%$ according to recent studies $(5,28)$. The significance of this disease with regard to the economic losses and its negative effect on animal welfare and health is considerable and should not be underestimated $(6,13,17)$.

\section{PHENOTYPIC CHARACTERIZATION}

\section{Clinical Signs and Treatment}

The clinical signs of PCS were first described in the late 1960's (29) and are visible directly after birth or within the 1 st $h$ of live. Affected animals exhibit a characteristic position of the hind limbs, which are deflected laterally and in severe cases, also the forelimbs are spread sideways (Figure 1). These signs differ in their expression and lead to difficulties or complete inability to stand and walk, which limits or even prevents suckling. In addition, affected piglets are at a high risk to be crushed by the sow. In cases with milder clinical signs, diseased piglets are able to overcome the critical period of postnatal paresis and apparent self-healing occurs within the 1st week of life (30). Permanent damage is not detectable and the splay leg piglets do not significantly differ in growth and phenotype from their healthy littermates (4). Common treatment methods of less affected animals are tying the hind limbs during the 1st days to improve overall mobility and to ensure proper nutrition by accessing the teats of the sow. With these simple but laborintensive measures the chances for survival of the affected piglets increase significantly, even though a medical treatment is not available.

\section{Muscular Phenotype}

Besides the obvious clinical signs, splay leg affected piglets show subtle histological findings. A histological myofibrillar deficiency in splay leg piglets leading to a muscular weakness was described alongside the syndrome's first scientific mention (29). Back then, Thurley et al. (29) introduced the term myofibrillar hypoplasia (MFH) to describe a histological pattern where only few numbers of small myofibers are found in the muscle section, which are also concentrated in a small part of the area enclosed by the endomysium. Due to rigorous investigation of a large number of different skeletal muscles, they also found $\mathrm{MFH}$ occurrence decreasing in the order hind limb $>$ lumbar region $>$ forelimb (29). Since recognized methods for thorough, objective histological studies were missing when PCS was first described, early studies on the extent of MFH might have been somehow biased by their subjective nature (2). 


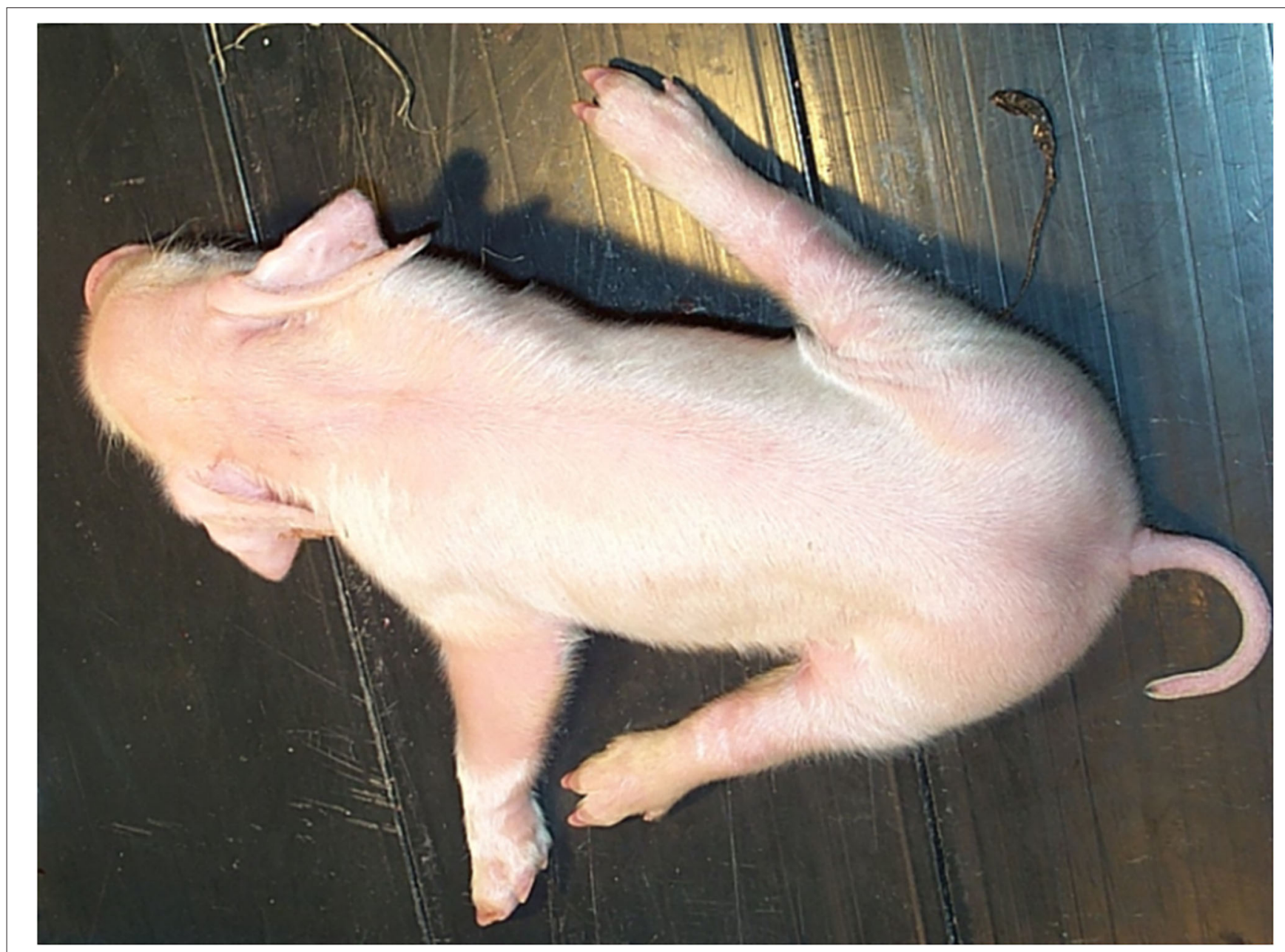

FIGURE 1 | Typical phenotype of a splay leg piglet. The hind legs are splayed sideward impairing the ability to stand and walk. The degree of splaying differs and fore legs are affected in severe cases, too.

A more conclusive study, involving a total of 24 affected piglets and controls and an extensive set of histological methods, was capable of setting up a more comprehensive picture of PCS histology (10). Beside the known MFH, staining for glycogen, ATPase and acetylcholine esterase (ACHE) revealed the presence of impaired muscular differentiation in PCS-affected piglets. In particular, using acid pre-incubated ATPase-reaction, the authors found only small numbers of solitary type I fibers in PCSaffected samples. This points to a striking delay in conversion of type II to type I myofibers, a main component of postnatal muscle maturation. In addition, ACHE-staining showed clear differences between larger, well-organized motor endplates in controls compared to smaller and more chaotically organized ones in splay leg samples (10).

Due to high variation in fiber morphology, early studies were not able to quantify the amount of MFH reliably by measuring and comparing the mean muscle fiber areas. Furthermore, healthy neonatal piglets may have myofibers with a very small diameter that indeed resemble MFH, thus making it difficult to diagnose PCS based solely on histopathology in some cases (31).

Other studies defined the degree of MFH as distribution of muscle fibers per area unit instead measuring fiber diameters only. Modeling distributions from both, healthy and affected animals, showed clear differences in muscle fiber density, and size distribution (32). Development of semi-automatic measurement methods allowed evaluation of larger numbers of muscle fibers and led to establishment of MFH as a key feature in PCS-piglets. It is now accepted that a higher number of smaller, less matured myofibrils characterizes PCS. These changes are expressed to a different extent in different muscles $(5,16)$.

Earlier results also supported the notion that an incomplete maturity of the skeletal muscles in affected animals is present at the time of birth (12). The reason why hind leg muscles are predominantly affected might be the slightly earlier development of fore limbs during embryogenesis (33). This is in concordance with early results of Deutsch and Done (34) showing that the 
muscular phenotype of splay leg piglets corresponded to those of 80-day-old porcine fetuses (34).

There is also the agreement that piglets, which recovered from the disease, show no differences in histology compared to clinically healthy animals $(7,35)$.

\section{Cellular Phenotype}

Already four decades ago, researchers employed electron microscopy to analyze skeletal muscle of PCS piglets at the ultrastructural level. Although, limited in numbers of investigated animals, striking differences between PCS-affected and control animals regarding the number, distribution and shape of cellular organelles were observed $(7,9)$. Again, the high variability of PCS-affected piglets prevented valid, general conclusions with regard to pathogenic mechanisms.

The most direct link between ultrastructural abnormalities and the pathology of PCS was the finding of disturbed morphology of the contractile elements. Morphologic disarray occurs in form of Z-discs with a streaming pattern in one or several adjacent myofibrils. Whole filaments seemed to be disarranged because myosin and actin were apparently misaligned. The affected sarcomeres appeared thin and often disrupted (9). Muscle fibers with extensive MFH contained differentiating myofibrils with incomplete or defective assembly of myofilaments (7). It is very comprehensible that such ultrastructural disarray leads to an impaired function of affected muscles.

Further studies showed that the sarcoplasmic reticulum was dilated and t-tubules were small and misshaped. Lysosomes and lipid droplets were found more frequently within the sarcoplasm while mitochondria were evenly distributed instead of being adjacent to the sarcolemma in normal piglets (36).

Atypical mitochondria were also observed in rabbits suffering from a syndrome with certain similarity to PCS. Mitochondria of affected animals were unevenly distributed and irregularly shaped. Sometimes mitochondria extended along the length of several sarcomeres (37).

Disarranged, misshaped mitochondria with probably impaired functional properties might therefore be responsible for the repeatedly observed phenomenon of splay leg muscles showing an increased accumulation of glycogen compared with the muscles of normal piglets. Here, the fibers that are lacking myofibrillar structure are filled with granular accumulations which were independently identified as glycogen stores $(10,34,36,38)$. Normally, fast depletion of glycogen takes place during the first $24 \mathrm{~h}$ after birth and muscle glycogen even decreased by $50 \%$ within the first $12 \mathrm{~h}$ after birth $(39,40)$. Thus, other mechanisms such as loss of contractile function due to structural disarray and the resulting decreased energy expenditure for physical activity, suckling and thermoregulation and/or impaired mitochondrial function might contribute to a reduced glycogen metabolism and development of higher numbers of glycogen granules.

Another intriguing hypothesis was an impairment of muscle innervation due to incomplete electrical isolation of primary motor neurons. Unfortunately, only a single study focusing on the nerval aspect of motor functions was published so far (41). According to this study, PCS-affected piglets suffer from loss of proper muscle innervation due to impaired Schwann-cell maturation leading to inefficient myelin sheathing. Extrapyramidal tracts and parts of the corticospinal tract were found largely unmyelinated in an analysis of the lumbar spinal cord of PCS-affected animals. The obturator nerve also showed a significant loss of myelin sheath thickness and a decreased overall axonal diameter while the number of axons was not changed (41).

\section{Biochemical Characteristics}

Since histological features of PCS resemble that of degenerative myopathies, activities of muscle specific enzymes [alanineaminotransferase (ALAT), aspartate-aminotransferase (ASAT), creatinine-phosphate-kinase (CPK), and lactate dehydrogenase $(\mathrm{LDH})]$ in blood plasma were measured as markers of a modified muscle cell membrane permeability. An early study suggested increases in ASAT, ALAT CPK, and LDH plasma levels as characteristic for PCS (42) but further studies on plasma and supernatants from tissue homogenates were inconclusive $(43,44)$. Measurements of other enzymes (e.g., $\mathrm{Ca}^{2+}$-ATPase in nervous system, catalase as key enzyme of peroxide depletion) as well as of metabolites and serum proteins (glucose, a2-macroglobulins, and ascorbic acid) sometimes revealed significant differences between PCS and control groups. However, the results could not be convincingly related to a pathogenic mechanism for the syndrome (45-47). Changes in $\mathrm{K}^{+}$-distribution are also in line with a supposed loss of cellular membrane integrity (42). However, the collective data suggested, that PCS was different from all myopathies described in other species.

Splay leg samples showed reduced DNA amounts and reduced protein: DNA ratios in certain muscles of the hind leg $(11,12)$. This was interpreted as delayed skeletal muscle development in low-birthweight PCS piglets. Inefficient or absent muscle innervation could be a reason for the delayed maturation or degeneration leading to muscular dysfunction. An increased $\mathrm{Ca} 2+-$ and $\mathrm{Na}+$-content measured in certain skeletal muscles of the hind limbs of splay leg piglets, supported the assumption of a neuromuscular background of the disease (11). In addition, the nutritional aspect was analyzed in detail with regard to mineral nutrients and trace elements, though significant differences in PCS compared to healthy piglets were found in neither of the tested tissues (43).

Based on an early finding that dietary supplementation of choline to pregnant sows seemed to prevent the occurrence of splay leg animals (6), later investigations focused on choline metabolism. Insufficient choline supply was considered as either a cause for a lack of choline phospholipids as membrane components or to be causing disorders in signal transduction by a lack of acetylcholine as transmitter. Even a modified degradation of acetylcholine was considered (44). This was supported by positive effects of the administration of the acetylcholine esterase blocker neostigmine-methylsulfate on the incidence of PCS (21). However, these results have not been confirmed in other studies $(44,48,49)$. In contrast, it was shown that PCS-affected animals showed significantly increased acetylcholine esterase activities in cerebellum, brain stem and spinal cord (50). Moreover, activity 
of choline acetyl transferase, which is responsible for synthesis of acetylcholine, was instead reduced in nerve tissues of splay leg affected animals (51). It seems that both, synthesis and degradation of acetylcholine, are disturbed in splay leg piglets and a probable disarray in muscle innervation might be at least partially involved in the expression of clinical signs.

Taken together, biochemical analyses of tissues and plasma from PCS piglets underline the heterogeneity of the syndrome as it was already noted for muscular and cellular phenotypes. Still though, data consistency suffers from low sample numbers, nonstandardized phenotypes, and different time points of sampling.

\section{GENETIC CHARACTERIZATION OF THE SPLAY LEG SYNDROME}

Even a decade after the initial description (29), PCS was often considered a consequence of insufficient intrauterine nutrition $(6,20)$. Nevertheless, numerous investigations presented convincing evidence for a genetic background of PCS $(26,52-$ 54). Because environmental factors exerted a major influence on incidence and severity of the syndrome (55), it was noted that an environmental "threshold" seemed to be necessary for clinical manifestation of PCS (18). Quantitative, genetic analyses revealed an oligo- or polygenic heredity with an estimated heritability of up to $0.47(22,54)$.

Initial molecular genetic approaches isolated expressed sequence tags (ESTs) unique to splay leg piglets in order to identify potential candidate genes $(14,56)$. Subsequent candidate analyses however, could not establish a systematic link to the syndrome $(57,58)$. More targeted analyses became feasible with increasing knowledge of the porcine genome and transcriptome. Since it was not clear, whether the observed MFH was a result of delayed muscle growth and differentiation or an atrophic process, structural proteins and atrophy markers were investigated (5). The authors found several muscular structural proteins like the MYH genes MYH1, MYH4, and MYH7 to be downregulated in PCS transcriptomes. The atrophy marker FBXO32 (MAFbx) was significantly overexpressed along with a clearly decreased expression of the yet unknown P311 protein (5), later identified as trans-differentiation regulator NREP which is known to be responsible for cell differentiation (59). The question whether muscle atrophy was cause or effect of impaired muscle maturation remained unanswered. Moreover, the differential expression of FBXO32 and P311 was not confirmed in an independent study (60).

When technological advances allowed the analysis of whole transcriptomes, the idea was quite tempting to deduce affected signaling networks just from the identified differentially expressed genes (DEG). The first microarray-based analysis on three hind limb muscles (M. sartorius, M gracilis, and Mm. adductores) of newborn PCS piglets and controls revealed only about two dozen DEGs with just a handful of genes with differential expression in all investigated muscles (15). These commonly affected genes were for example part of a universal expression response to multiple stressors (DDIT4), involved in regulation of protein degradation (SQSTM1), acting as transcriptional co-activator (SSRP1), transcription factor (MAF), or are involved in differentiation processes (ENAH). All of them appear quite coherent regarding the given clinical and histological phenotype. DDIT4 for example, known to act as an mTOR inhibitor, has been identified as a key regulator of muscular mass. Since muscle mass is in result dependent on the net balance of constant protein biosynthesis and protein degradation, impaired mTOR activity can shift the balance toward decreased protein synthesis and increased ubiquitin-dependent proteasome activity and autophagy (61). Increased expression of SQSTM1 also fits the frame due to its role as an autophagy adaptor protein being involved in shuttling ubiquitinated proteins toward the proteasome (62). Besides the aspect of muscle atrophy, also the impaired muscle differentiation observed in PCS-affected animals was backed up by certain DEGs. SSRP1 for example is one compound of the FACT (Facilitates chromatin transcription) complex that is responsible for expression of critical genes in muscle differentiation which it facilitates in a myogenin-dependent manner. It is needed during the early steps of muscle cell differentiation but it can only interact with its target genes in the presence of myogenin (63). Also, MAF, a well-known transcription factor involved in cellular differentiation, plays, in feedback with other transcription factors of the MRF (myogenic regulatory factor) family, an important role in myogenic differentiation (64). Its differential expression found in PCSaffected vs. control animals therefore supports the histological picture of delayed muscle differentiation. Another example of DEGs initially found using micro-array approaches was ENAH. This protein is involved in nucleation and polymerization of actin and is therefore involved in virtually every aspect of cellular functions which require actin reorganization [i.e., cell migration, cell-cell or cell-matrix adhesion, and cell differentiation (65)].

RNA-sequencing of unspecified hind leg muscle samples of 2-day old PCS and control piglets later revealed more than 1,000 genes with unique expression in one of both groups and 555 DEGs (16). The large number of DEGs allowed pathway enrichment analyses and identified a number of cellular signaling pathways including steroid biosynthesis, PI3KAkt signaling, the phagosome, and ECM-receptor interaction. In the end, all of the significantly enriched pathways play crucial roles in differentiation and cellular growth (steroid biosynthesis), tissue remodeling and inflammation (phagosome), tissue and organ morphogenesis as well as maintenance of cell and tissue structures (ECM-receptor interactions), while the PI3K-Akt-signaling pathway regulates the most fundamental cellular functions like growth, transcription and survival. It was concluded that PI3K-Akt signaling is somehow suppressed in PCS leading to dephosphorylation of FOXO transcription factors toward overexpression of FBXO32 (16) which has been linked to muscle atrophy in PCS before (5). Although, the results of transcriptome analyses provided starting points for subsequent candidate investigations, they comprise only a snapshot of the gene activity in a specific tissue at the very moment of sampling and do not allow for discriminating between cause and consequence of the syndrome (Table 1). It should be kept in mind that few key nodes control many 
TABLE 1 | Selected candidate genes for porcine congenital splay leg identified by gene expression analyses.

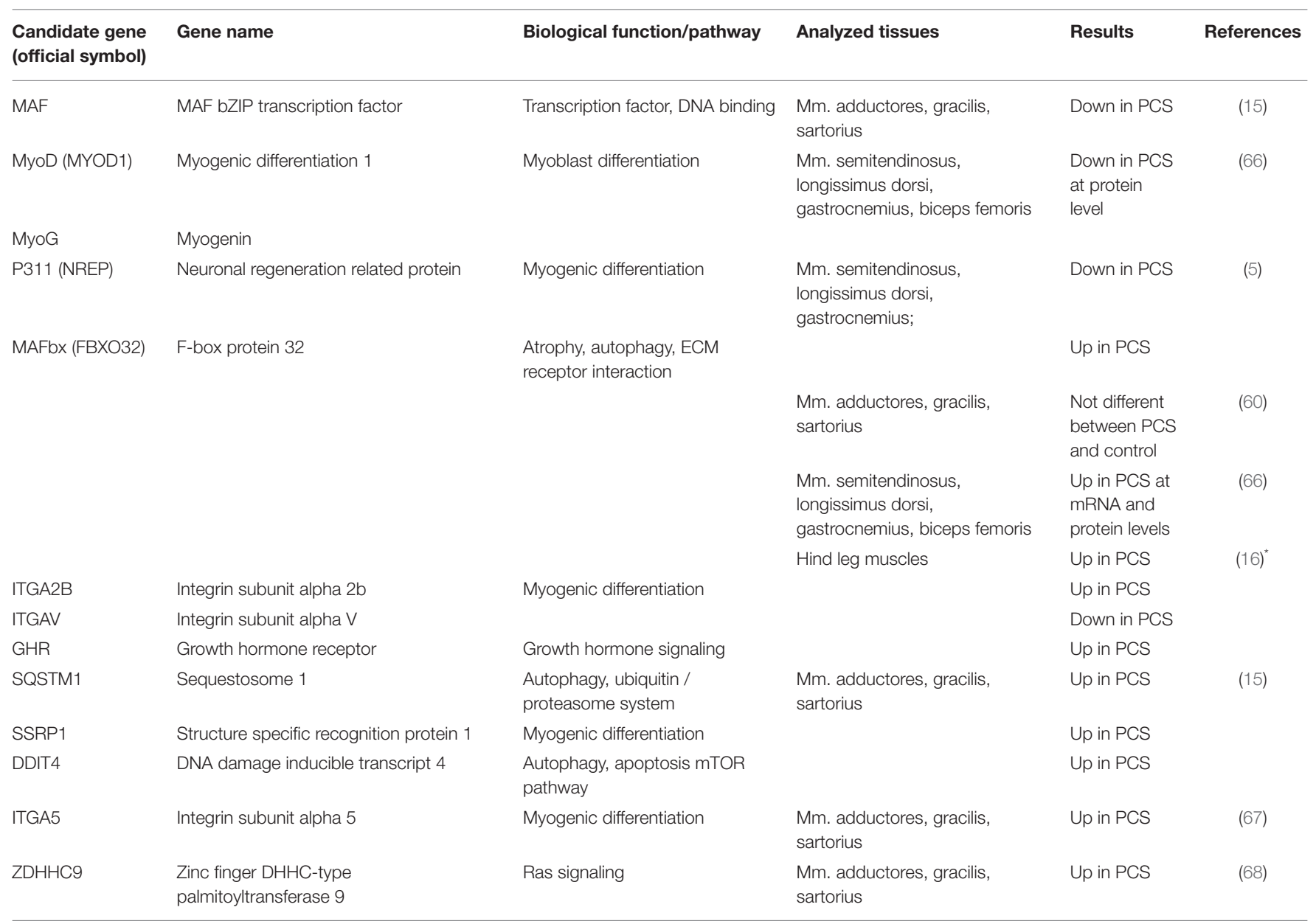

${ }^{*}$ a total of 555 genes differentially expressed between PCS and control piglets have been identified.

cellular pathways where minute changes in activity could affect a plethora of subsequent regulation cascades, while their own expression levels might change only marginally and oftentimes undetectably. Thus, such key players might be overlooked in these experimental approaches.

Consequently, mapping of genetic variation linked to the PCS was applied in parallel experiments. First, a quantitative trait locus (QTL) analysis in a resource population based on microsatellites identified two suggestive QTL-intervals on SSC5, and SSC11 linked to the PCS phenotype. In these large QTLintervals, 11 potential candidate genes were identified (69). Since NFYB (Nuclear transcription factor Y, beta), was found to be differentially expressed before (14) and is located within the QTL on SSC5 it underwent scrutiny with regard to its genomic sequence and expression. Even though a sex difference in NFYB expression was observed, a relationship to PCS was finally excluded (58). No further candidate genes from this first QTL screen were considered later on. Although, QTL mapping promised identification of potentially causal variation at genome level, it was hindered by the need for sufficiently large resource populations and the low density of available markers comprising microsatellites in the beginning. This explains that no further studies have been published.

Only recently, a genome wide association study was performed in a case/control design in five different pig populations that gained new insights (17). Following this approach, seven chromosome-wide significant SNPs were identified on five porcine autosomes (SSC1, SSC2, SSC7, SSC15, and SSC16) but none of the SNPs reached genome-wide significance level. This might be attributed to the limited population size as well as to the rather strict correction for multiple testing. Notably, SSC5 and SSC11 identified by Schwarz (69) as QTL-harboring autosomes before, were not confirmed by this study. The seven SNPs were located in a distance between 0 and roughly $200 \mathrm{~kb}$ to a neighboring gene. Of these seven, two SNPs were located only $18 \mathrm{~kb}$ from or directly within homer scaffold protein 1 (HOMER1) on SSC2, and two further SNPs in an intergenic region on SSC15, 97 and $120 \mathrm{~kb}$ apart from transition protein 1 [TNP1; (17)]. Although, the latter two SNPs seem not to relate to an obvious candidate gene for PCS it is conceivable that a not yet annotated non-coding gene might be the carrier of the respective SNPs. More interestingly, two SNPs 
are located close to and within HOMER1, a gene previously linked to muscle related processes. Even though the specific function of HOMER1 has not been studied in pigs sufficiently, it is already known to be involved in muscle differentiation and calcium homeostasis (70), leading to myopathy in mice when expression is lost (71) and exhibited lower expression in a mouse model of Duchenne's muscular dystrophy (72). A follow up study (73) focused directly on the sequence of porcine HOMER1, defined the promoter regions and analyzed a total of 21 SNPs in the same population used in their previous analysis (17). Twelve of the SNPs were significantly associated with PCS making HOMER1 a promising candidate for PCS (Table 2).

In a completely different approach, a large-scale ENU (Nethyl-N-nitrosourea) mutagenesis screen was performed in pigs and generated more than 100 families with dominantly or recessively inherited traits (66). In one family, a phenotype of hind limb paresis resembling PCS was observed. Withinfamily mapping of the variation underlying this phenotype revealed a $1 \mathrm{Mb}$ region on SSC4 spanning 18 genes, among them the previously identified FBXO32. Subsequent analyses showed increased expression of FBXO32 mRNA and protein in three PCS-like piglets compared to three controls. Furthermore, MyoD and MyoG but not MYF5 were significantly downregulated in PCS-like piglets (Table 1). At histological level, interstitial fibrosis was observed in hind leg and longissimus muscles but not in fore limb muscles of affected piglets.

\section{CURRENT STATUS}

Decades of phenotypical description at different levels lead to a rather heterogeneous picture of the syndrome. Most work was concentrated on skeletal muscle tissue and myofibrillar hypoplasia of the affected hind legs, and also on the $\mathrm{M}$. longissimus. MFH was therefore considered a common feature of splay leg in piglets. Besides MFH being a consequence of an immaturity of the muscular system at birth, an involvement of the nervous system was discussed as well. Specifically, a disturbed stimulus conduction, probably resulting from insufficient activity of acetylcholine and/or dysregulation of synaptic calcium metabolism, was further considered. In addition, metabolic disturbances like an impaired glycogen metabolism at the early postnatal period were discussed at length. However, many of the studies involved only a low number of piglets at different early postnatal time points and often lacked a clear phenotypic description.

A number of environmental factors are considered to be involved in or related to the expression of the PCS phenotype [reviewed in (24)]. This conclusion was derived from several studies reporting effects of nutrition, induced farrowing, housing conditions and diseases on the incidence of PCS. Insufficient choline supply of the sow was considered as cause of PCS by some authors $(6,44)$. This could lead either to reduced availability of choline phospholipids as membrane components or to a disordered signal transduction in skeletal muscle of the piglets (44). Indeed, dietary supplementation of choline to pregnant sows first seemed to prevent the occurrence of splay leg animals (6). PCS symptoms apparently disappeared after injection of the acetylcholine esterase blocker neostigmine-methylsulfate (21). However, these results could not be confirmed in other studies $(48,49)$. Furthermore, neither choline plasma levels nor activities of various choline esterases were found to be reduced in PCS piglets (44).

Induced farrowing as a common practice in the industrial pig production was also discussed as a possible cause of splay leg syndrome from the 1970's until recently (54). It was shown that induced farrowing increased the relative rate of piglet morbidity (74), but further studies found only a weak correlation between reduction of gestation length by induced farrowing and the incidence of PCS $(54,75,76)$.

The porcine reproductive and respiratory syndrome (PRRS) was also suspected as being responsible for PCS. This virus infection results, among others, in reproductive failure including an increased number of abnormal piglets born. Vaccination against the PRRS virus was related to an immediate reduction of PCS piglets (77). However, there was no correlation found between anti-PRRSV vaccination and PCS incidence in a larger, more recent study (78). Although, vaccination significantly decreased reproductive problems, the number of PCS piglets did not differ between the treatments in three studied herds (78). In summary, environmental factors are likely to be involved in the modulation of PCS frequency and phenotypic expression but are unlikely as primary cause of the syndrome (Figure 2).

With the availability of molecular genetic methods in animal science, several studies aimed at identification of genetic causes for PCS. Besides global, transcriptional analyses of different muscles of affected piglets, also targeted, hypothesis-driven

TABLE 2 | Structural analyses of candidate genes for PCS.

\begin{tabular}{|c|c|c|c|c|}
\hline Candidate gene & Gene name & $\begin{array}{l}\text { Biological } \\
\text { function/pathway }\end{array}$ & Results & References \\
\hline CDKN3 & $\begin{array}{l}\text { Cyclin dependent kinase } \\
\text { inhibitor } 3\end{array}$ & Cell cycle, carcinogenesis & $\begin{array}{l}\text { No association of } 12 \text { single nucleotide polymorphisms } \\
\text { (SNPS) with PCS }\end{array}$ & $(57)$ \\
\hline ITGA5 & Integrin subunit alpha 5 & Myogenic differentiation & No association of a SNPin the $3^{\star}-U_{T R}^{*}$ with PCS & $(67)$ \\
\hline $\mathrm{ZDHHC9}$ & $\begin{array}{l}\text { Zinc finger DHHC-type } \\
\text { palmitoyltransferase } 9\end{array}$ & Ras signaling & No variation between PCS and control & $(68)$ \\
\hline HOMER 1 & Homer scaffold protein 1 & $\begin{array}{l}\text { Muscle development, } \\
\text { glycogen metabolism }\end{array}$ & $\begin{array}{l}12 \text { of } 19 \text { SNPs related to PCS, } 1 \text { SNP changes activity of } \\
\text { an internal promoter }\end{array}$ & (73) \\
\hline
\end{tabular}

*3'-UTR: 3'untranslated region. 


\section{Extrinsic Risk Factors}

\section{Intrinsic Risk Factors}

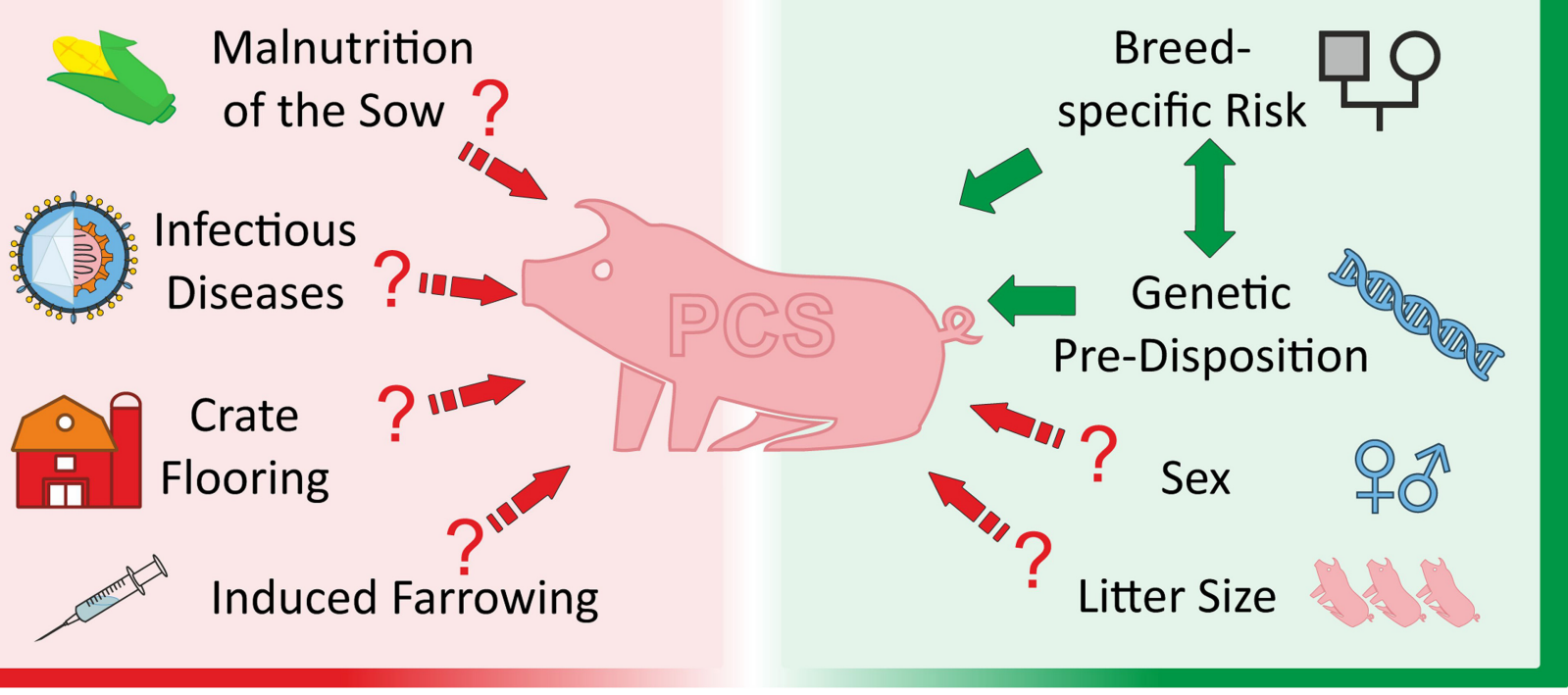

FIGURE 2 | Overview about extrinsic and intrinsic factors discussed as causal and/or modulating factors for porcine congenital splay leg.

approaches toward putative functional candidates were conducted. As a result, several candidates were named but again, sampling of various muscles at differential time-points prevented broad comparability of the data. With the upcoming of GWAS as a powerful tool to identify phenotype-related genome variations, several chromosomal regions containing PCS-related SNPS were identified. The increasing detail of porcine genome annotation nowadays facilitates the listing of genes for further consideration.

Combining all published results, evidence for two putative pathological mechanisms evolved: Muscle fiber atrophy as suggested by the upregulation of the atrophy marker FBXO32 and delayed maturation of skeletal muscle at birth.

Latest research has presented two promising candidate genes potentially involved in either one of the proposed pathogenetic mechanisms. FBXO32 was not only identified in targeted as well as in global transcriptome analyses $(5,16)$ but its chromosomal region harbors genetic variants (66). HOMER1 was also found to contain specific SNPs using GWAS (17) which seem to alter the expression of certain isoforms via a modified intronic promotor (73). All studies were performed in different populations indicating a general validity (Tables 1,2$)$.

\section{PERSPECTIVES}

A brief look into selected aspects of the proteins' physiology encoded by the most promising candidates underlines the opportunities opening up for future research.

First, FBXO32, also known as MAFbx, which is encoding an E3 ubiquitin ligase and therefore is considered as an early marker of atrophy in different species $(5,79,80)$ might be causative for the observed retarded muscle maturation. Not only is the ubiquitin-proteasome pathway responsible for protein degradation which is typical for skeletal muscle atrophy (81), other results also suggest a negative regulation of MyoD1 and MyoG-both being master regulators of myogenesis-by FBXO32 (66). This underlines the importance of this factor for a multitude of processes in muscle development and growth. Although, no investigations on variations in the FBXO32 locus have been reported yet, future studies might still identify a genetic predisposition resulting in altered FBXO32 expression with implications for PCS. Furthermore, targeting upstream factors of FBXO32 like members of the FOXO family or the PI3K-Akt-pathway (16) might be useful for understanding the FBXO32-dependent aspect of PCS etiology.

Second, HOMER 1 as a member of the Homer protein family which is predominantly found in neural tissues is also expressed in muscle cells $(82,83)$ where it is directly involved in skeletal muscle differentiation. Homer proteins interact with numerous ligands [e.g., type 1 inositol trisphosphate (IP3) receptor, ryanodine receptor, and $\alpha-1 \mathrm{D}$ adrenergic receptor (84)]. With regard to muscle tissue, especially their binding capacity of intracellular ligand-gated $\mathrm{Ca}^{2+}$ channels like $\mathrm{IP}_{3} \mathrm{R}$ and RyR is a crucial aspect of Homer activity since activation of transcription factors such as MEF2 (85) or NFAT (86) are critical in muscle differentiation. Disturbances in the equilibrium of HOMER expression is therefore likely to impair such processes. Proper orchestration of muscular transcriptomes is essential for functional muscles. Its impairment might consequently result in the observed atrophy-like situation, and retarded muscle development. Because Homer proteins are critically involved in glutamatergic signaling, which is crucial for 
neuronal cells triggering and controlling myelination processes in oligodendroglia precursors $(87,88)$, it can be surmised that HOMER dysfunctions might also impair proper motor axon myelination (89). This may lead to improper muscle innervation as reported by Szalay et al. (41) for PCS piglets. Since certain SNPs have already been reported near or within the HOMER locus (17) and also seem to effectively modulate Homer isoform expression (73), this candidate might be the most promising in the search for the cause of the hereditary trait of PCS.

It should be noted that PCS is most likely a quantitative trait with at least a moderate number of genes involved. As summarized above, different physiological processes may be dysregulated in splay leg piglets. It is likely that further candidates will come into focus and add important facets to the picture. P311 (NREP) might be such an example since it is already known to be downregulated in splay leg piglets. This trans-differentiation factor is important for cell development and might therefore also fit the picture as a causing factor of MFH. Moreover, binding of HOMER to calcium channels regulates the activity of downstream transcription factors like NFAT which is critical for muscle differentiation (86). Interestingly, about one third of the differentially expressed genes identified in the study of Maak et al. (15) are direct targets of NFAT. Consequently, several pathways could be followed in parallel to contribute to a comprehensive elucidation of PCS' etiology and pathogenesis.

Future tasks to meet this aim could include the identification of causal variation leading to differential expression of certain candidates (e.g., FBXO32, NREP) as well as the functional characterization of identified SNPs (e.g., HOMER1). All candidates should be investigated in different populations to find general mechanisms causing PCS. Most importantly, clinical and histological parameters as well as experimental conditions

\section{REFERENCES}

1. Muirhead M, Alexander T. Managing and treating disease in the farrowing and suckling period. In: J Carr, editor, Managing Pig Health: A Reference for the Farm. Sheffield: 5M Publishing (2013). p. 227-82.

2. Thurley DC, Done JT. The histology of myofibrillar hypoplasia of newborn pigs. Zentralbl Veterinaermed. (1969) 16:73240. doi: 10.1111/j.1439-0442.1969.tb00557.x

3. Olson LD, Prange JF. Spraddle-legged baby pigs. Vet Med Small Anim Clin. (1968) 63:714.

4. Dewey CE. Diseases of swine. In: B Straw, J Zimmerman, S D'Allaire, D Taylor, editors, Diseases of swine. Ames, IA: Blackwell Publishing Ltd (2006). p. 87-111.

5. Ooi PT, Da Costa N, Edgar J, Chang KC. Porcine congenital splayleg is characterised by muscle fibre atrophy associated with relative rise in MAFbx and fall in P311 expression. BMC Vet Res. (2006) 2:23. doi: 10.1186/1746-6148-2-23

6. Cunha T. Spraddled hind legs may be a result of a choline deficiency. Feedstuffs. (1968) 40:25.

7. Bergmann V. Elektronenmikroskopische Befunde an der Skelettmuskulatur von neugeborenen Ferkeln mit Grätschstellung. Arch Exp Veterinaermed. (1976) 30:239-60.

8. Dobson KJ. Congintal splayleg of piglets. Aust Vet J. (1968) 44:268. doi: 10.1111/j.1751-0813.1968.tb04909.x have to be clearly defined and reported with sufficient detail to describe the phenotype as accurately as possible. Standardization of muscle sampling-anatomical location and timing-is of crucial importance for gene or protein expression studies. This would greatly enhance the comparability of different studies.

Since clinical and histological findings might still be highly biased by a plethora of vital parameters, isolation of muscle stem and progenitor cells, also known as satellite cells, would be a very useful tool in order to test the intrinsic differentiation capacity of cells derived from PCS piglets and controls in vitro.

Despite many uncertainties regarding the phenotypic and genetic background of PCS, still existing, recent studies have paved the road toward understanding this syndrome. Molecular genetics will enable pig breeders to select against porcine congenital splay leg in a foreseeable time.

\section{AUTHOR CONTRIBUTIONS}

SM and TS conceived the review. TS wrote the draft. TS, SM, and MR edited the manuscript. All authors contributed to the article and approved the submitted version.

\section{FUNDING}

The publication of this article was funded by the Open Access Fund of the Leibniz Institute for Farm Animal Biology (FBN) Dummerstorf.

\section{ACKNOWLEDGMENTS}

We want to thank Lisa Schering and Claudia Miersch for introducing conceptual ideas and for reviewing and collecting the literature.
9. Zelená J, Jirmanová I. Degenerative changes in skeletal muscles of piglets with congenital myofibrillar hypoplasia. Zentralbl Veterinaermed. (1979) 26:65265. doi: 10.1111/j.1439-0442.1979.tb01643.x

10. Hanzlíková V. Histochemical patterns in normal and splaylegged piglet muscle fibers. Histochemistry. (1980) 67:311-9. doi: 10.1007/BF00692763

11. Hillert S, Kolb E, Buchner A. Untersuchungen uber den Gehalt an DNA, RNA, Protein und Nichtprotein-N in Geweben von normal entwickelten Ferkeln sowie von Gratschferkeln sehr unterschiedlicher Geburtsmasse. 1. Ergebnisse der Analysen des Gross-und des Kleinhirns, der Pons mit Medulla oblongata. Arch Exp Veterinaermed. (1987) 41:65-77.

12. Elschner M, Kolb E, Müller I, Vallentin G. Untersuchungen über den Gehalt an DNA, RNA und Gesamtprotein in verschiedenen Skelettmuskeln, im Zwerchfell, in der rechten und linken Herzkammer sowie in der Muskulatur des Ösophagus, des Magens und der Harnblase von normal entwickelten Ferken und von Grätschferkeln unterschiedlicher Körpermasse. Arch Exp Veterinaermed. (1991) 45:131-45.

13. Lax T. Hereditary splayleg in pigs. J Hered. (1971) 62:2502. doi: 10.1093/oxfordjournals.jhered.a108162

14. Maak S, Jaesert S, Neumann K, Yerle M, von Lengerken G. Isolation of expressed sequence tags of skeletal muscle of neonatal healthy and splay leg piglets and mapping by somatic cell hybrid analysis. Anim Genet. (2001) 32:303-7. doi: 10.1046/j.1365-2052.2001.00778.x

15. Maak S, Boettcher D, Tetens J, Wensch-Dorendorf M, Nürnberg G, Wimmers $\mathrm{K}$, et al. Identification of candidate genes for congenital splay leg in piglets 
by alternative analysis of DNA microarray data. Int J Biol Sci. (2009) 5:3317. doi: $10.7150 /$ ijbs.5.331

16. Wu T, Zhang X, Tian M, Tao Q, Zhang L, Ding Y, et al. Transcriptome analysis reveals candidate genes involved in splay leg syndrome in piglets. J Appl Genet. (2018) 59:475-83. doi: 10.1007/s13353-018-0454-5

17. Hao X, Plastow G, Zhang C, Xu S, Hu Z, Yang T, et al. Genomewide association study identifies candidate genes for piglet splay leg syndrome in different populations. BMC Genet. (2017) 18:64. doi: 10.1186/s12863-017-0532-4

18. Köhler R, Seffner W. Angeborenes beinspreizen bei saugferkeln. Mh Vet Med. (1974) 29:259-65.

19. Maass D, Schulze J. Zur genetischen Disposition des angeborenen Beinspreizens bei Saugferkeln. Mh Vet Med. (1979) 34:20-2.

20. Hörügel $\mathrm{K}$, Lorenz A. Untersuchungen zum angeborenen Beinspreizen bei Ferkeln in einer industriemäßig produzierenden Zuchtanlage. Mh Vet Med. (1979) 34:183-4.

21. Schnapperelle H, Koch J. Occurrence and treatment of congenital splayleg in unweaned piglets. Mh Vet Med. (1980) 35:858-69.

22. Stigler J, Distl O, Kruff B, Kräusslich H. Segregationsanalyse von Erbfehlern beim Schwein. Züchtungskunde. (1991) 63:294-305.

23. Wrathall A. The boar and congenital problems. Pig Vet Soc Proc. (1988) 21:116-34.

24. Papatsiros V. The splay leg syndrome in piglets: a review. Am J Anim Vet Sci. (2012) 7:80-3. doi: 10.3844/ajavsp.2012.80.83

25. Van Der Heyde H, De Mets JP, Porreye L, Henderickx H, Calus A, Bekaert H, et al. Influence of season, litter size, parity, gestation length, birth weight, sex and farrowing pen on frequency of congenital splayleg in piglets. Livest Prod Sci. (1989) 21:143-55. doi: 10.1016/0301-6226(89)90045-6

26. Vogt D, Gipson T, Dover S, Ellersieck M. Associations of sire, breed, birth weight, and sex in pigs with congenital splayleg. Am J Vet Res. (1984) 45:24089.

27. Partlow GD, Fisher KR, Page PD, MacMillan K, Walker AF. Prevalence and types of birth defects in Ontario swine determined by mail survey. Can J Vet Res. (1993) 57:67-73.

28. Abah KO, Itodo JI, Ubah SA, Shettima I. Reproductive performance of pigs raised by intensive management system in Abuja, Nigeria. Vet World. (2019) 12:305-8. doi: 10.14202/vetworld.2019.305-308

29. Thurley D, Gilbert F, Done J. Congenital splayleg of piglets: myofibrillar hypoplasia. Vet Rec. (1967) 80:302-4. doi: 10.1136/vr.80.9.302

30. Madson DM, Arruda PHE, Arruda BL. Nervous and locomotor system. In: JJ Zimmerman, LA Karriker, A Ramirez, KJ Schwartz, GW Stevenson, J Zhang, editors, Diseases of Swine. Hoboken, NJ: John Wiley \& Sons (2019). p. 339-72. doi: 10.1002/9781119350927.ch19

31. Ward PS, Bradley R. The light microscopical morphology of the skeletal muscles of normal pigs and pigs with splayleg from birth to 1 week of age. J Comp Pathol. (1980) 90:421-31. doi: 10.1016/0021-9975(80)90012-2

32. Cox CS, Baskerville A, Ward PS. Quantitative image analysis of skeletal muscle from newborn pigs with myofibrillar hypoplasia and splayleg. $\mathrm{Br} \mathrm{Vet}$ J. (1979) 135:370-5. doi: 10.1016/S0007-1935(17)32840-3

33. Bininda-Emonds ORP, Jeffery JE, Sanchez-Villagra MR, Hanken J, Colbert MW, Pieau C, et al. Forelimb-hindlimb developmental timing differences across tetrapod phylogeny. BMC Evol Biol. (2007) 7:182. doi: $10.1186 / 1471-2148-7-182$

34. Deutsch K, Done JT. Congenital myofibrillar hypoplasia of piglets: ultrastructure of affected fibres. Res Vet Sci. (1971) 12:176-7. doi: 10.1016/S0034-5288(18)34217-6

35. Ducatelle R, Maenhout D, Coussement W, Hoorens JK. Spontaneous and experimental myofibrillar hypoplasia and its relation to splayleg in newborn pigs. J Comp Pathol. (1986) 96:433-45. doi: 10.1016/0021-9975(86)9 0039-3

36. Antalíková L, Horák V, Matolín S. Ultrastructural demonstration of glucose-6-phosphatase activity and glycogen in skeletal muscles of newborn piglets with the splayleg syndrome. Reprod Nutr Dev. (1996) 36:20512. doi: 10.1051/rnd:19960205

37. Joosten HFP, Wirtz P, Verbeek HOF, Hoekstra A. Splayleg: a spontaneous limb defect in rabbits. Genetics, gross anatomy, and microscopy. Teratology. (1981) 24:87-104. doi: 10.1002/tera.1420240110
38. Zelená J, Smetana K, Jirmanová I. Abnormalities of the nuclear envelope in porcine muscle affected with congenital myofibrillar hypoplasia. Virchows Arch B Cell Pathol. (1978) 28:157-65.

39. Dalrymple RH, Hamm R. A method for the extraction of glycogen and metabolites from a single muscle sample. Int J Food Sci Technol. (1973) 8:439-44. doi: 10.1111/j.1365-2621.1973.tb01730.x

40. Hakkarainen J. Developmental changes of protein, RNA, DNA, lipid, and glycogen in the liver, skeletal muscle, and brain of the piglet. A methodological and experimental study with special reference to protein synthesis. Acta Vet Scand Suppl. (1975) 59:1-198.

41. Szalay F, Zsarnovszky A, Fekete S, Hullár I, Jancsik V, Hajós F. Retarded myelination in the lumbar spinal cord of piglets born with spread-leg syndrome. Anat Embryol. (2001) 203:53-9. doi: 10.1007/s004290000129

42. Patterson DSP, Sweasey D, Allen WM, Berrett S, Thurley DC The chemical composition of neonatal piglet muscle and some observations on the biochemistry of myofibrillar hypoplasia occurring in otherwise normal litters. Zentralbl Veterinaermed. (1969) 16:741-53. doi: 10.1111/j.1439-0442.1969.tb00558.x

43. Kolb E, Grodrian A, Dittrich H, Nestler K. Untersuchungen über den Gehalt verschiedener Gewebe von gesunden bzw. von Grätschferkeln an Trockenmasse an Ca, Mg, Na, K und Gesamt-P. Mh Vet Med. (1981) 36:904-8.

44. Tuček S, Svoboda T, Ríčný J, Bass A, Soukup T, Vítek V. The concentration of choline and the activities of cholinesterases, creatine kinase and lactate dehydrogenase in the blood plasma of piglets with the syndrome of splayleg (congenital myofibrillar hypoplasia). Zentralbl Veterinaermed. (1985) 32:110. doi: 10.1111/j.1439-0442.1985.tb01908.x

45. Leo M, Kolb E, Rohland C, Schineff C, Gründel G. Untersuchungen uber die Aktivitat von ATPasen im Nervensystem von Feten, von gesunden Ferkeln und von Gratschferkeln. Arch Exp Veterinaermed. (1986) 40:406-8.

46. Kolb E, Wahren M, Dobeleit G, Gründel G. The content of ascorbic acids in different tissues of cattle, normally developed piglets, splay-legged piglets, adult swine and dogs. Arch Exp Veterinarmed. (1989) 43:327-34.

47. Svendsen L, Weström B, Svendsen J, Olsson A, Karlsson B. Blood serum characteristics of newborn pigs: comparison of unaffected pigs with pigs belonging to fire mortality groups. Acta Vet Scand. (1991) 32:28799. doi: 10.1186/BF03546957

48. Dobson KJ. Failure of choline and methionine to prevent splayleg in piglets. Aust Vet J. (1971) 47:587-90. doi: 10.1111/j.1751-0813.1971.tb02076.x

49. Maxwell C V., Johnson RK, Luce WG. Effect of level of protein and supplemental choline on reproductive performance of gilts fed sorghum diets. J Anim Sci. (1987) 64:1044-50. doi: 10.2527/jas1987.6441044x

50. Le Hong T, Kolb E, Mueller I, Vallentin G. Untersuchungen über die Aktivität der Acetylcholinesterase im zentralen Nervensystem von gesunden sowie von Grätschferkeln mit unterschiedlicher Körpermasse. Mh Vet Med. (1990) 45:243-51.

51. Wittner S, Kolb E, Jaehnichen S, Klug E. Untersuchungen uber die Aktivitat der Cholinacetyltransferase und der Acetylcholinesterase in verschiedenen Abschnitten des Nervensystems sowie der Skelettmuskulatur von neugeborenen Ferkeln mit normaler bzw. geringer Korpermasse sowie bei Ferkeln mit Stehunvermögen (Ausgrätschen). Arch Exp Veterinaermed. (1982) 36:221-35.

52. Jirmanová I, Lojdá L. Dexamethasone applied to pregnant minisows induces splayleg in minipiglets. Zentralbl Veterinaermed. (1985) 32:44558. doi: 10.1111/j.1439-0442.1985.tb01962.x

53. Björklund N, Svendsen J, Svendsen L. Histomorphological studies of the perinatal pig: comparison of five mortality groups with unaffected pigs. Acta Vet Scand. (1987) 28:105-16. doi: 10.1186/BF03548261

54. Sellier P, Dando É, Dando P. Induction of parturition in the sow and incidence of splayleg syndrome in the newborn piglet. Anim Res. (1999) 48:153-61. doi: 10.1051/animres:19990301

55. Christison G, Lewis N, Bayne G. Effects of farrowing crate floors on health and performance of piglets and sows. Vet Rec. (1987) 121:3741. doi: $10.1136 /$ vr.121.2.37

56. Maak S, Jaesert S, Neumann K, von Lengerken G. Rapid communication: nucleotide sequence and physical mapping of the porcine cyclindependent kinase inhibitor 3 (CDKN3) gene. J Anim Sci. (2002) 80:1698-9. doi: $10.2527 / 2002.8061698 x$ 
57. Maak S, Jaesert S, Neumann K, Von Lengerken G. Characterization of the porcine CDKN3 gene as a potential candidate for congenital splay leg in piglets. Genet Sel Evol. (2003) 35:157-65. doi: 10.1186/1297-9686-35-S1-S157

58. Boettcher D, Paul S, Bennewitz J, Swalve HH, Thaller G, Maak S. Exclusion of NFYB as candidate gene for congenital splay leg in piglets and radiation hybrid mapping of further five homologous porcine genes from human chromosome 12 (HSA12). Cytogenet Genome Res. (2007) 118:6771. doi: 10.1159/000106443

59. Stradiot L, Mannaerts I, van Grunsven LA. P311, friend, or foe of tissue fibrosis? Front Pharmacol. (2018) 9:1151. doi: 10.3389/fphar.2018.01151

60. Boettcher D, Schmidt R, Rehfeldt C, Thaller G, Swalve H, Maak S. Evaluation of MAFbx expression as a marker for congenital splay leg in piglets. In: M Pinard, C Gay, P Pastoret, B Dodet, editors, Animal Genomics for Animal Health. Basel: Karger (2008). p. 301-6. doi: 10.1159/000317175

61. Zhao J, Zhai B, Gygi SP, Goldberg AL. MTOR inhibition activates overall protein degradation by the ubiquitin proteasome system as well as by autophagy. Proc Natl Acad Sci USA. (2015) 112:157907. doi: 10.1073/pnas.1521919112

62. Komatsu M, Kageyama S, Ichimura Y. P62/SQSTM1/A170: physiology and pathology. Pharmacol Res. (2012) 66:457-62. doi: 10.1016/j.phrs.201 2.07.004

63. Lolis AA, Londhe P, Beggs BC, Byrum SD, Tackett AJ, Davie JK. Myogenin recruits the histone chaperone facilitates chromatin transcription (FACT) to promote nucleosome disassembly at muscle-specific genes. J Biol Chem. (2013) 288:7676-87. doi: 10.1074/jbc.M112.426718

64. Cabello G, Casas F, Wrutniak-Cabello C. Transcription factors and muscle differentiation. In: A Giordano, U Galderisi, editors, Cell Cycle Regulation and Differentiation in Cardiovascular and Neural Systems. New York, NY: Springer (2010). p. 35-68. doi: 10.1007/978-1-60327-153-0_3

65. Gurzu S, Ciortea D, Ember I, Jung I. The possible role of Mena protein and its splicing-derived variants in embryogenesis, carcinogenesis, and tumor invasion: a systematic review of the literature. Biomed Res Int. (2013) 2013:365192. doi: 10.1155/2013/365192

66. Hai T, Cao C, Shang H, Guo W, Mu Y, Yang SS, et al. Pilot study of large-scale production of mutant pigs by ENU mutagenesis. Elife. (2017) 6:e26248. doi: 10.7554/eLife.26248

67. Maak S, Boettcher D, Komolka K, Tetens J, Wimmers K, Reinsch N, et al. Exclusion of sequence polymorphisms in the porcine ITGA5 and MIR148B loci as causal variation for congenital splay leg in piglets. Anim Genet. (2010) 41:447-8. doi: 10.1111/j.1365-2052.2010.02047.x

68. Maak S, Boettcher D, Tetens J, Swalve HH, Wimmers K, Thaller G. Expression of microRNAs is not related to increased expression of ZDHHC9 in hind leg muscles of splay leg piglets. Mol Cell Probes. (2010) 24:327. doi: 10.1016/j.mcp.2009.09.001

69. Schwarz S. Kartierung von Loci für kongenitales Ausgrätschen beim neugeborenen Ferkel. (dissertation). Christian-Albrechts-Universität zu Kiel, Kiel, Germany. (2002).

70. Lin CY, Chen JS, Loo MR, Hsiao CC, Chang WY, Tsai HJ. MicroRNA3906 regulates fast muscle differentiation through modulating the target gene homer-1b in zebrafish embryos. PLoS ONE. (2013) 8:e70187. doi: 10.1371/journal.pone.0070187

71. Stiber JA, Zhang Z-S, Burch J, Eu JP, Zhang S, Truskey GA, et al. Mice lacking homer 1 exhibit a skeletal myopathy characterized by abnormal transient receptor potential channel activity. Mol Cell Biol. (2008) 28:263747. doi: 10.1128/MCB.01601-07

72. Long C, McAnally JR, Shelton JM, Mireault AA, Bassel-Duby R, Olson EN. Prevention of muscular dystrophy in mice by CRISPR/Cas9-mediated editing of germline DNA. Science. (2014) 345:1184-8. doi: 10.1126/science.12 54445

73. Xu S, Hao X, Zhang M, Wang K, Li S, Chen X, et al. Polymorphisms of HOMER1 gene are associated with piglet splay leg syndrome and one significant SNP can affect its intronic promoter activity in vitro. BMC Genet. (2018) 19:110. doi: 10.1186/s12863-018-0701-0

74. Gunvaldsen RE, Waldner C, Harding JC. Effects of farrowing induction on suckling piglet performance. J Swine Health Prod. (2007) 15:84-91. Available online at: https://www.aasv.org/shap/issues/v15n2/v15n2p84.html
75. Walker N. The effects of induction of parturition in sows using an analogue of prostaglandin F $2 \alpha$. J Agric Sci. (1977) 89:267-71. doi: 10.1017/S0021859600028173

76. Smith HM, Selby CC, Williams AM, Ellersieck MR, Lamberson WR, Safranski TJ. Induction of farrowing with cloprostenol on a commercial pig breeding farm in Yugoslavia. J Swine Health Prod. (2013) 21:195202. doi: 10.1136/vr.103.21.469

77. Papatsiros VG, Alexopoulos C, Kritas SK, Koptopoulos G, Nauwynck HJ, Pensaert $\mathrm{MB}$, et al. Long-term administration of a commercial porcine reproductive and respiratory syndrome virus (PRRSV)-inactivated vaccine in PRRSV-endemically infected sows. J Vet Med Ser B. (2006) 53:26672. doi: 10.1111/j.1439-0450.2006.00965.x

78. Jeong J, Kim S, Park KH, Kang I, Park SJ, Park C, et al. Evaluation of the effect of a porcine reproductive and respiratory syndrome (PRRS) modifiedlive virus vaccine on sow reproductive performance in endemic PRRS farms. Vet Microbiol. (2017) 208:47-52. doi: 10.1016/j.vetmic.2017.07.016

79. Bodine SC. Identification of ubiquitin ligases required for skeletal muscle atrophy. Science. (2001) 294:1704-8. doi: 10.1126/science.1065874

80. Lecker SH, Jagoe RT, Gilbert A, Gomes M, Baracos V, Bailey J, et al. Multiple types of skeletal muscle atrophy involve a common program of changes in gene expression. FASEB J. (2004) 18:39-51. doi: 10.1096/fj.03-0610com

81. Mitch WE, Goldberg AL. Mechanisms of muscle wasting-the role of the ubiquitin-proteasome pathway. N Engl J Med. (1996) 335:1897905. doi: 10.1056/NEJM199612193352507

82. Soloviev MM, Ciruela F, Chan WY, McIlhinney RAJ. Mouse brain and muscle tissues constitutively express high levels of homer proteins. Eur J Biochem. (2000) 267:634-9. doi: 10.1046/j.1432-1327.2000.01078.x

83. Volpe P, Sandri C, Bortoloso E, Valle G, Nori A. Topology of homer 1c and homer 1a in C2C12 myotubes and transgenic skeletal muscle fibers. Biochem Biophys Res Commun. (2004) 316:884-92. doi: 10.1016/j.bbrc.2004.02.132

84. Tu JC, Xiao B, Yuan JP, Lanahan AA, Leoffert $\mathrm{K}$, Li M, et al. Homer binds a novel proline-rich motif and links group 1 metabotropic glutamate receptors with IP3 receptors. Neuron. (1998) 21:717-26. doi: 10.1016/S0896-6273(00)80589-9

85. Friday BB, Mitchell PO, Kegley KM, Pavlath GK. Calcineurin initiates skeletal muscle differentiation by activating MEF2 and MyoD. Differentiation. (2003) 71:217-27. doi: 10.1046/j.1432-0436.2003.710303.x

86. Friday BB, Pavlath GK. A calcineurin- and NFAT-dependent pathway regulates Myf5 gene expression in skeletal muscle reserve cells. J Cell Sci. (2001) 114:303-10. Available online at: https://jcs.biologists.org/content/114/ 2/303.long

87. Gautier HOB, Evans KA, Volbracht K, James R, Sitnikov S, Lundgaard $\mathrm{I}$, et al. Neuronal activity regulates remyelination via glutamate signalling to oligodendrocyte progenitors. Nat Commun. (2015) 6:8518. doi: 10.1038/ncomms9518

88. Spitzer S, Volbracht K, Lundgaard I, Káradóttir RT. Glutamate signalling: a multifaceted modulator of oligodendrocyte lineage cells in health and disease. Neuropharmacology. (2016) 110:57485. doi: 10.1016/j.neuropharm.2016.06.014

89. Benedetti F, Poletti S, Locatelli C, Mazza E, Lorenzi C, Vitali A, et al. A Homer 1 gene variant influences brain structure and function, lithium effects on white matter, and antidepressant response in bipolar disorder: a multimodal genetic imaging study. Prog Neuropsychopharmacol Biol Psychiatry. (2018) 81:88-95. doi: 10.1016/j.pnpbp.2017.10.011

Conflict of Interest: The authors declare that the research was conducted in the absence of any commercial or financial relationships that could be construed as a potential conflict of interest.

Copyright (C) 2021 Schumacher, Röntgen and Maak. This is an open-access article distributed under the terms of the Creative Commons Attribution License (CC BY). The use, distribution or reproduction in other forums is permitted, provided the original author(s) and the copyright owner(s) are credited and that the original publication in this journal is cited, in accordance with accepted academic practice. No use, distribution or reproduction is permitted which does not comply with these terms. 